\title{
Nursing care for a person with invasive devices, intensive care unit, of hospital of Chiclayo
}

\begin{abstract}
Summary
Objective: It is to reveal nursing care to people with invasive devices in the intensive care unit.

Method: Qualitative research with a case study approach. The sample was 10 nurses.

Results: Nursing care in people with devices emphasizes the biomedical competences in the care of invasive devices, prioritizing biosecurity in care, reducing the discomfort of the person who worries about unveiling team work, integrating spirituality in the care of Nursing, prioritizing biosecurity in care, reveals teamwork. Considering the person and the family in the care.
\end{abstract}

Conclusion: Nursing care requires biomedical competences, which not only consider the person in the dimension physical, biological, but psychological, spiritual, integrate the person and family in the care of invasive devices.

Keywords: nursing care, invasive devices, intensive care
Volume 2 Issue 3 - 2018

\author{
Lilia Jannet Saldarriaga Sandoval,' Rina \\ Noemi Cuzquen Sandoval, ${ }^{2}$ Emily Sugey \\ Castillo Cieza ${ }^{2}$ \\ 'Magister em Ciencias en Enfermeria, Docente Universidad \\ Nacional de Tumbes- Especialista Hospital Regional, Peru \\ ${ }^{2}$ Graduada en enfermería, Especialista Hospital Nacional \\ Almanzor Aguinaga Asenjo, peru
}

\begin{abstract}
Correspondence: Lilia Jannet Saldarriaga Sandoval, Magister em Ciencias en Enfermeria, Docente Universidad Nacional de Tumbes- Especialista Hospital Regional, Lambayeque, Peru,
\end{abstract} Email liyasa45@hotmail.com

Received: February 12, 2018 | Published: June 15, 2018
Abbrivetaions: NHSN, national healthcare safety network; ICU, intensive care units;

\section{Introduction}

The Importance of nursing care today is indisputable, it is even affirmed that nursing is the practice of care that is improved with the application of scientific knowledge. ${ }^{1}$ Care is defined as an act of reciprocity that is tended to be made with any person who requires assistance to meet their vital needs, temporarily or permanently. ${ }^{2}$ The care Is based on theoretical knowledge that facilitates the interpretation and the analysis of the care between the cared person and the carer, allowing them to build a solidary human interaction. ${ }^{3}$ People in critical condition present dissatisfaction with various needs, which may cause danger to bodily organs and systems; whit loss of independence, an increased risk of infection, and requires assistance to satisfy basic requirements. ${ }^{4}$ That help you recover your health through the use of invasive procedures, against chronic diseases requires multiple antibiotics, more prolonged stays, which also imply restrictions and limitations in communication, generating low self-esteem, malaise, suffering, physical and emotional pain. ${ }^{5-7}$ Invasive devices are of various uses; whose most common uses are for the administration of solutions in large volumes, enteral nutrition solutions, antibiotic therapy, inotropes, hemodynamic monitoring, Hemodialysis, drainage, etc; Have a severe risk of infection, generally related to length of stay and nursing care. ${ }^{8}$

Globally, on average, 1 out of every 20 hospitalized patients is affected, which corresponds to an annual total of 4.1 million patients, the main cause being the use of medical devices. En modernos establecimientos de salud de países desarrollados: 5 a $10 \%$ de los pacientes adquieren una o más infecciones. En los países en vías de desarrollo, el riesgo de IAAS es 2 a 20 veces superior que en los países desarrollados y la proporción de los pacientes afectados por IAAS puede superar el $25 \%$. En las unidades de terapia intensiva: $30 \%$ de los pacientes y la mortalidad atribuida puede alcanzar el $44 \%$ siendo las causas principales por uso de dispositivos invasivos. ${ }^{9}$
The National Healthcare Safety Network (NHSN) the incidence of catheter-associated infection in intensive care units(ICUs) and general medical care is 1.2 per thousand day catheters and can reach up to 3.7 in burn units, this incidence demonstrates the importance of preventive actions by the nursing staff and Infections associated with health care (IAAS).$^{10-12}$ The rates of device-associated infections are much higher in ICUs in Latin American countries compared to those hospitals in US., due to lack of infection control programs, hospital accreditation, and limited resource.es for policy implementation in Latin American countries. ${ }^{13}$ In our country, was reported the incidence of intrahospital infections associated with invasive devices in intensive care units of the Cayetano Heredia National Hospital, study observational retrospective during the years 2010 to 2012 . A total of 222 infections were reported in hospital, the Intensive Care Unit of Medicine had the incidence per 1000 days of use of the highest device for pneumonia associated with mechanical ventilator $(28,6)$; Central venous catheterassociated bloodstream infection $(11,9)$, and catheter-associated urinary tract infection $(8,1) .{ }^{14}$ Theoretical reference that makes us ask the question: How is Nursing Care for people with invasive devices in the Intensive Care Unit? To answer the question was raised the goal; Disclose nursing care to a person with invasive devices in the Intensive Care Unit of the Hospital. The motivation arises from the experience of seeing the presence of one or more invasive devices in the majority of people hospitalized depending on the pathology they present and its usefulness, therefore, it is important to unveil the Nursing care to the security risk and produce local or systemic infection is very high and represents a health problem.

\section{Material and methods}

According to the objective the qualitative type was chosen with the Case Study approach. ${ }^{3,15}$ The methodological trajectory according to the Case Study, 18, is developed in three phases:

It was performed in the Intensive Care Unit located on the Hospital, has 10 beds where people are hospitalized in critical condition, with degree of total dependence, with average stay is seven days, the, 
common diagnoses are sepsis by urinary, respiratory, gastrointestinal, traumas, in immediate postoperative of Cardiac Surgeries etc. as well as other predicted pathologies; are in a state of sleep or coma and are connected to a mechanical fan; Which requires the use of multiple invasive devices such as nasogastric probes, Foley probes, central venous catheter drainage, etc. that require a specialized handling.

We proceeded to collect the necessary information in a systematic way, for which we used: Participant observation, in-depth interview and documentary analysis, facilitating the realization of triangulation of all sources. With the information the thematic analysis was carried out, after the transcription of the interviews recorded considering at all times the ethical and emic aspects, we proceeded to the identification of the units of meaning that were constituted in nuclei from which they will be generated The categories, as a result, the report is produced. ${ }^{3,15}$ Starting from previous assumptions, by describing how Nurses take care of people who have some invasive device, considering important aspects, which meant changes that were discovered. We observed the intensive care unit with 10 rooms with moons that allows to visualize to the sick people that has invasive devices, implemented with equipment and materials, in which the nurse develops the care, how nursing care of people with invasive information revealing the knowledge, technologies, feelings, experiences, attitudes of the nurses. Data were collected at different times, subjects involved, and situations occurred during development, as the main source to nurses, a second source the family, and the third to records of medical records. For this reason, after transcribing the interviews, the categorization of the same was made taking into account the frequent speeches but also the anecdotes.

It was narrated their experiences, obtaining that the nurses can make natural generalizations, those that are given when the knowledge experienced by them in the moment that tries to associate the data found with the fruit of experiences Personal. So that the interested parties were able to compare their experiences with those found in other studies and presented in the results. The population consisted of the 25 nurses who work in the intensive care unit as well as the people with invasive devices attended in that service. The information collection period was January to May 2015. To obtain them, the following:

\section{Inclusion criteria:}

$i$. Friends who have as a year of experience in the unit

ii. People with at least one invasive device.

Exclusion criteria:

\section{i. Callers of other services that cover shifts}

ii. Persons in unconscious state.

For the delimitation of the sample was by saturation of the speech, being 10 nurses,

At all times the ethical principles and rigor of the scientific research required when it came to studies involving people were taken into account. ${ }^{16}$

\section{Analysis and discussion of results}

The observation made it possible to see how the nurse in everyday life and as a routine, prioritizes the review of devices, their Interrelation with the subject of care, begins with the greeting thus this unconscious, and communication with the members of the health team during The medical visit, with its intervention of the evolution of the patients, carries out its activities with haste, due to the complexity of the care without neglecting the biosecurity measures, as well as the support of the nurses at the moment of the patient's entry into the state serious. Much of their time is frequent monitoring, corresponding records and assessment of the person.

\section{Emphasizing biomedical competencies in the care of people with invasive devices}

The nursing staff shares with the medical staff the responsibility for the application and compliance of the measures of technical care, aseptic and biological implications during the placement, control and withdrawal of the devices assuming full responsibility for the care of both invasive and puncture devices and the various aseptic manipulations of perfusion lines (keys, equipment, solutions to be perfused, etc.) and finally responsible for the assessment of Signs of local and/or systemic infection as well as rigorous sampling to ensure real, reliable and timely microbiological results. The biomedical and curative aspects, reducing the human to the biological, and the human being is a disease or object of study. ${ }^{17}$

... The Protocols are fulfilled, I know them ... well, in them is written step by step each procedure, with which they are made, Foley probes are changed every 10 to 12 days...(G) ...The catheters are cured daily mostly in the morning because sometimes in the shifts there is no time, the days of placement in the graphic sheet are recorded when we see that it is within the limit of days we change them or we advise the doctor so that ... (A)

Considered that, in order to better define the social and ethical responsibilities of the nurse and to explain the implications of human care, it is necessary to rely on factors of care, as; Practice loving kindness and equanimity within the context of awareness of care develop and support an authentic caring relationship to support the expression of positive and negative feelings as a connection to the deeper spirit with oneself and the one to whom one cares. Creative use of all knowledge pathways, as part of the care process; participate in the art of healing-care practices, assisting with basic needs, with an awareness of deliberate care and managing essential human care that fosters the integration of mind-body-spirit and health-unity of being in all aspects of care. ${ }^{8}$

\section{Prioritizing biosecurity in care}

Biosecurity aims to protect the health and safety of health personnel and individuals in an intensive care unit, against different risks produced by: biological, physical, chemical and mechanical agents. ${ }^{17}$ Essalud has biosecurity standards that are designed to reduce the risk of transmission of microorganisms from recognized or unrecognized sources of infection, linked to accidents due to exposure to blood and body fluids. In this regard, in agreement with, nursing care should be based on knowledge of the pathways of contamination, to adopt preventive measures, such as hand washing And the performance of procedures with aseptic technique, management of invasive devices, among others; But these activities must be standardized to improve the quality of care, and so only specific knowledge and training is required. ${ }^{18}$

...Another aspect that we take care of is asepsis, everything has to be sterile, it is extremely important, we have to take great care of patients ... $(G)$... When removing a catheter I remove it in the box of sharp punctures,... (A) 
Taking into account the evidence the implementation of actions aimed at strengthening theoretical knowledge through constant training.

\section{Reducing the discomfort of the person cared for}

The perception of care subjects regarding the effects they suffer from the necessary and indispensable use of invasive devices, requiring the analysis of both the severity of the discomfort and how to reduce them, It is necessary that when assessing are made very accurate records that allow to guide the development of technology, seeking to contribute to decrease. ${ }^{19}$ To achieve this, the nurse needs to have a personal relationship with the subject of care through good communication, co-empathy and develop the ability to identify the person's psychological state to facilitate the identification of their comfort needs and their state of discomfort.

The care is all kind of concern, restlessness, restlessness, discomfort and even fear for people and realities with which it is affectively involved, and for that reason they are significant. ${ }^{20}$ In those situations where participatory care is not possible due to the health condition of the care subject, these are performed by specialized persons, involving a trained family member, with this it is possible to satisfy the social need of accompaniment, a climate of positive relation with the equipment and the familiar thus maintaining physical comfort. $^{8}$

...The roads sometimes cause discomfort to the patient we try to fix them well so that you do not pull the skin and it changes,.. (J.)... If I see that the patient is restless or tells me that something bothers him, I inspect the area Insertion of the catheter or the area where the discomfort occurs ... (A).

The consideration of the person and his care with dignity requires the participation of the family in the care as a satisfaction of necessity to be useful to the subject of care, the care is a way of being, of expressing oneself, of relating to oneself, to another being and to the world, it speaks of the human being as a being of care, all people are capable of caring, as a moral action, impregnated with values, and feelings, as an existential quality. ${ }^{21}$

\section{Unveiling teamwork}

Nursing care is an art because it unites the technological, intellectual and creative with the spiritual and if each individual is unique and unrepeatable, the nurse in providing care creates it according to the particular needs of each care subject, without being subordinate to the mechanical, considering that, in order to achieve this, it requires an interrelation of people with people and not between pieces of machinery. ${ }^{21}$ That within the health team, the nurse remains an important strategic resource in the prevention and control of infections associated with health care, in order to optimize patient care through the application of the fundamental principle of nursing: "Protect man from external agents that cause him illness."

...When an income comes, we all support, with catheters, solutions, ways to try to stabilize the person ...(J). ... We always support and try that the colleague who has an income implement all the treatment, facilitating the performance of procedures, monitoring and comfort according to the guides and protocols we have, to continue.. (G)

This perception is positive, evidence of teamwork using tools for better care, such as the study by Jara et.al., ${ }^{22}$ who proposes that the construction of care guides taking into account the epidemiological profile of the institution; Secondly, to implement clear institutional policies on the indication, installation, care and withdrawal of devices; As well as to carry out continuous education and training of personnel and follow-up of the compliance with the guidelines with the implementation of checklists, through which the pertinence of the devices.

\section{Integrating spirituality into nursing care}

A positive relationship between spirituality and health has generated a broad field of development so that nursing professionals can provide spiritual care should support the person as they identify and explore what it means in their lives and as they seek ways to adjust to the pain and suffering of illness. Spirituality is intrinsic to human nature and is the most profound and potent healing resource the person has y being is able to gradually develop his/her spirituality, this causes the nurse to require skills to provide spiritual care and must know how religious beliefs influence the person, offers a framework of structuring devotion, which provides relief, consolation. ${ }^{21}$

...Spiritual support in a personal way speaks to you of Christ, a song, somehow calmed down... (G) ... does not worry that God is by your side and guides and takes care of me I will not feel pain... (M).

The spiritual aspects of each person, caregiver and subject of care are established within the family and is strengthened by a relationship of intimacy and unique affection for what is considered this very necessary union that in times of illness is reaffirmed more in the person as in the family. ${ }^{15}$

\section{Considering the person and the family in the care}

The nurse practice and the principles inherent in care invite the nurse to a collaboration with the professional staff and not professionally, in this last relation the families have offered to their members varied care according to the experience of life, with the development of medical science the place of care has gradually been the hospital center.

In this context, the family has ceased to be recognized as carers and they have lost their informal network of knowledge exchanges and it is with the new paradigms that it is desired to integrate more effectively the family as a support system for the person who experiences a health experience.

...In the visit the relatives are coming to ask me why he has So many artifacts? I try to understand what their use is...(A).... Explain how it will be and what it will be, it is with anesthetic that will not cause you much pain AI. "'Today it is considered of great therapeutic values to consider the closeness of the family for short periods of time and with the proper orientation... $(G)$.

In nursing, self-care is a substantive action to be able to take care of others as ${ }^{2}$ points out, when he points out that there are three types of care: caring for oneself, caring for others and caring for others Which means that, in order to care for others, it is necessary to develop an awareness of serving their own needs. ${ }^{3}$

\section{Final considerations}

The care that the nurse provides with the development of biomedical competences, prioritizes biosecurity and discards sharps, assesses the person's discomfort when observing the person and the proper fixation of the devices, integrates spirituality into care, 
considers the person and family and Integra in care when explaining the use and Benefit of these, in addition to unveiling teamwork among professionals, during the person's income.

\section{Acknowledgements}

Our thanks to the advisor, for her motivation, and valuable permanent advice in the realization of the present study. To the Hospital for the facilities granted for the realization of this study, and to all those people who, in some way, are part of its completion.

\section{Conflict of interest}

The author declares no conflict of interests.

\section{References}

1. Errasti IB, Arantzamendi SM, Canga AN. La imagen social de la enfermería: una profesión a conocer. Anales del Sistema Sanitario de Navarra. 2012;35(2):269-283.

2. Colliére M. Promover la Vida. Colombia, USA: Mc Graw-Hill Interamericana; 1997.

3. Backes DS, Zamberlan CF, Barbosa DC. Del cuidado previsible al cuidado complejo de enfermería. Enfermería Global. 2014;13(36):275-281.

4. Silveira RCCP, Braga FTMM, Garbin LM, et al. The use of polyurethane transparent film in indwelling central venous catheter. Rev Latino-Am Enfermagem. 2010;18(6):1212-1220.

5. Diana Marcela Achury Saldaña, Yanier Betancourt Manrique, Diana Lorena Coral, et al. Intervenciones de enfermería para prevenir la neumonía asociada a ventilación mecánica en el adulto en estado crítico. Investigación en Enfermería: Imagen y Desarrollo. 2012;14(1):57-75.

6. Sherafat SJ, Razaghi M, Rosenthal VD, et al. Device associated infection rates and bacterial resistance in six academic teaching hospitals of Iran: Findings from the International Nosocomial Infection Control Consortium (INICC). Journal of Infection and Public Health. 2015;8(6):553-561.

7. Izquierdo ME. 2015. Enfermería: Teoría de Jean Watson y la inteligencia emocional, una visión humana. Revista Cubana de Enfermería. 31(3):1216.

8. Watson J. Caring science and the next decade of holistic healing: Transforming self and system from the inside out. Beginnings. 2010;30(2):11.

9. Centers for Disease Control and Prevention. Hagamos más segura la atención médica. 2017.
10. Díaz, L.A, et al. Prevención no farmacológica de la neumonía asociada a ventilación mecánica. Revista Archivos de bronconeumología. 2010;46(4):188-195.

11. De Melo G, et al. Percepción del cuidado de enfermería en un servicio de atención prenatal: Montería. Universidad Nacional de Colombia; 2013.

12. Allegranzi B, Bagheri S, Combescure C, et al. Burden of endemic healthcare-associated infection in developing countries: systematic review and meta-analysis. Lancet. 2011;377(9761):228-241.

13. Dudeck MA, Weiner LM, Allen-Bridson K, et al. National Healthcare Safety Network (NHSN) report, data summary for 2012, Deviceassociated module. Am J Infect Control. 2013;41(12):1148.

14. Omayra Chincha, Elia Cornelio, Violeta Valverde, et al. Infecciones intrahospitalarias asociadas a dispositivos invasivos en unidades de cuidados intensivos de un hospital nacional de Lima, Perú. Rev Perú med exp salud pública. 2013;30(4).

15. Polit DF, Beck CT. Fundamentos de pesquisa em enfermagem. 7 ed. Porto Alegre: Artmed; 2011. 670 p.

16. Informe Belmont. Principios Éticos y directrices para la protección de sujetos Humanos de Investigación. 2008.

17. Espiau M, Pujol M, Campins M, et al. Incidencia de bacteriemia asociada a catéter venoso central en una unidad de cuidados intensivos. In Anales de Pediatría. 2011; 75(3):188-193.

18. Báez F, RM, Samudio M. Conocimientos, actitudes y prácticas del personal de enfermería sobre medidas de prevención de neumonías asociadas a la ventilación mecánica en la unidad de cuidados intensivos de adultos del Instituto de Previsión Social. Memorias del Instituto de Investigaciones en Ciencias de la Salud. 2013;11(1):22-30.

19. Rodríguez JS, Cárdenas-JM, Pacheco AAL, et al. Una mirada fenomenológica del cuidado de enfermería. Revista Enfermeria Universitaria. 2014;11(4).

20. Boff L. El cuidado esencial. Ética de lo humano compasión por la tierra. Trota, Tapa blanda; 2002. 168 p.

21. Waldow VR. El cuidado integral del ser humano. Memorias del III Congreso Internacional y V Nacional de Enfermería en Cuidado Humano. Facultad de Ciencias de la Salud, Universidad de Carabobo; 2013. p. 5362.

22. Jara PA, Carmona MFJ, Martínez LM. Carga de trabajo de enfermería en una unidad de cuidados intensivos y su relación con las infecciones nosocomiales. Revista Nure. 2011;8(51). 